\title{
Physical Quality Indicators of an Oxisol Under Grass in the Agreste Region of Paraiba, Brazil
}

\author{
Pedro Luan F. da Silva ${ }^{1}$, Flávio P. de Oliveira ${ }^{1}$, Camila C. da Nóbrega ${ }^{1}$, Adriana F. Martins ${ }^{1}$, Walter E. Pereira ${ }^{2}$, \\ Igor Gabriel dos S. O. Botelho ${ }^{1}$, Danillo Dutra Tavares ${ }^{3} \&$ Tales Emanuel Duarte Santos ${ }^{4}$ \\ ${ }^{1}$ Department of Soil and Rural Engineering, Federal University of Paraiba, Areia, Paraíba, Brazil \\ ${ }^{2}$ Department of Fundamental and Social Sciences, Federal University of Paraíba, Areia, Paraíba, Brazil \\ ${ }^{3}$ Department of Agronomy, Rural Federal University of Pernambuco, Recife, Pernambuco, Brazil \\ ${ }^{4}$ Department of Soil Science, Federal University of Lavras, Lavras, Minas Gerais, Brazil \\ Correspondence: Pedro Luan F. da Silva, Department of Soil and Rural Engineering, Federal University of \\ Paraiba, Areia, PB, 58397-000, Brazil. Tel: 55-83-99869-9512. E-mail: pedroluanferreira@gmail.com
}

Received: July 7, 2019 Accepted: August 8, $2019 \quad$ Online Published: September 15, 2019

doi:10.5539/jas.v11n15p65 URL: https://doi.org/10.5539/jas.v11n15p65

\begin{abstract}
The aim of this study was to evaluate the influence of different grass cultivars on physical attributes of an Oxisol in the Agreste region of Paraíba. The experiment was set up in 2005 in experimental areas of the Center of Agricultural Sciences of the Federal University of Paraíba, Areia-PB. The experimental design adopted was that of randomized complete blocks (RCB) with 5 treatments and 4 replications, in experimental plots of $50 \mathrm{~m}^{2}$. The treatments were the following: I. Brachiaria decumbens Stapf., II. Brachiaria brizantha, III. Brachiaria humidicola (Rendle) Schweickvr., IV. Brachiaria brizantha cv. MG5-Vitória and V. Brachiaria ruziziensis. In October 2018 samples of soil with disturbed and undisturbed structure were collected at the center of each experimental plot in the depth of $0.0-0.10 \mathrm{~m}$ for the determination of the following variables: soil porosity (total, macro and micro), bulk density, compaction degree, saturated hydraulic conductivity, field capacity, permanent wilting point, available water content, soil aeration capacity, clay dispersed in water, flocculation degree and aggregate stability index. The analysis of variance was performed and the means were compared by Tukey's tests, principal component analysis and Pearson's correlation analysis $(p<0.05)$. It is concluded that after the 13-year period, Brachiaria brizantha promoted improvements to the field capacity of the Oxisol. The other attributes were not physically altered. Main component analysis showed that the correlation values were more significant for the Brachiaria brizantha component. Pearson's correlation was significant between field capacity and soil aeration capacity.
\end{abstract}

Keywords: soil physics attributes, Brachiaria, aggregates stability index, bulk density, hydraulic conductivity

\section{Introduction}

The land usage and management system, when performed incorrectly can alter the physical attributes of the soil, promote degradation, reduce quality and cause damage to its sustainability. In general, the factors of greatest impact on the physical and structural quality of the soil are the excessive traffic of agricultural machines and input of agricultural implements, animal trampling (Gasparetto et al., 2009), predatory removal of vegetation cover (Sales et al., 2018) and surface burning of residues (Redin et al., 2011).

The physical degradation of the soil reflects directly on its structural quality, varying through different degrees of intensity. When the soil structure changes negatively, there may be a reduction in crop productivity due to changes in water retention and availability, oxygen diffusion, soil resistance to root penetration (Guimarães et al., 2014) and aggregates stability (Bonini \& Alves, 2011).

Different attributes have been used to evaluate soil physical quality, such as: bulk density, macroporosity, microporosity, total porosity, aggregates stability, soil penetration resistance (Lima et al., 2014) and saturated hydraulic conductivity, for being a parameter of great importance in the water movement through the soil (Soto \& Kiang, 2018). 
Generally, in production systems where vegetation cover is suppressed, changes in soil physical attributes occur, reducing the sustainability of agricultural production, especially in environments with climatic irregularities. In this context, it is noted an urgent need to adopt management systems that maximize food production, without compromising the physical properties of the soil. The maintenance of the vegetation cover has been used in a quite satisfactory way in conservationist production systems, considering the physical improvements that it promotes in the soil, especially in situations of low water availability (Costa et al., 2007; Oliveira et al., 2018).

The maintenance of permanent vegetation cover with grasses favors numerous improvements to the environment, especially the reduction in erosion rate caused by surface runoff (Silva et al., 2018), improvements in water productivity and availability indexes (Braga et al., 2017) and formation of aggregates with higher stability index (Santos et al., 2012). All of this derives from the action of the root system, which, depending on the species cultivated, may show a higher or lower intensity of improvement in the physical attributes of the soil.

Thus, knowing the importance of the vegetation cover for the improvement of the physical attributes of the soil and the lack of information about which species of the Brachiaria genus are more efficient in this improvement, this study aimed to evaluate the influence of different cultivars of grasses of such genus on physical attributes of anOxisol in the Agreste region of Paraíba.

\section{Method}

\subsection{Characterization of the Experimental Area}

The experiment was set up in 2005 in an experimental area belonging to the Center of Agricultural Sciences of the Federal University of Paraíba, in Areia-PB. The city is located within the micro-region of Brejo and mesoregion of the Agreste of Paraíba $\left(6^{\circ} 58^{\prime} 12^{\prime \prime} \mathrm{S} ; 35^{\circ} 41^{\prime} 15^{\prime \prime} \mathrm{W}\right.$; and altitude of $\left.620 \mathrm{~m}\right)$. In 2017 the micro-region of the Brejoparaibano was inserted in the climatic domain of the Brazilian Semiarid region (Dry lands), due to the irregularities in the local climate, caused by poor rainfall distribution and the increase in the annual average temperature (SUDENE, 2017).

According to Köppen classification, the predominant climate in the municipality is As'-tropical, hot and humid, with rains during autumn and winter and mean annual precipitation of $1400 \mathrm{~mm}$ (Almeida et al., 2014), with $62.0 \%$ occuring between April and July. The annual mean temperature is $24.5^{\circ} \mathrm{C}\left(75.2{ }^{\circ} \mathrm{F}\right)$ and the relative humidity of the air ranges in average of $\mathrm{RH}=80.0 \%$ (Carmo et al., 2012). The soil of the experimental area is classified as Dystrophic Yellow Oxisol (Santos et al., 2018), with sandy-clay-loam texture. The physical and chemical characterization of the soil can be found in Tables 1 and 2, respectively.

Table 1. Physical soil characterization of the experimental area for the layer of $(0.0-0.10 \mathrm{~m})$

\begin{tabular}{|c|c|c|c|c|c|c|c|c|c|}
\hline \multicolumn{5}{|c|}{ Sand } & \multirow{2}{*}{ Silt } & \multirow{2}{*}{ Clay } & \multirow{2}{*}{ Textural classification* } & \multirow{2}{*}{$\mathrm{S} / \mathrm{C}$} & \multirow{2}{*}{ PD } \\
\hline $\mathrm{VC}$ & $\mathrm{C}$ & $\mathrm{M}$ & $\mathrm{F}$ & VF & & & & & \\
\hline$---\cdot$ & 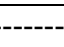 & --- & $\mathrm{g} \mathrm{kg}$ & 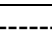 & ----. & --- & & & $\mathrm{g} \mathrm{cm}^{-3}$ \\
\hline 43 & 199 & 196 & 112 & 24 & 69 & 357 & Sandy clay loam & 0.194 & 2.58 \\
\hline
\end{tabular}

Note. $\mathrm{VC}=$ Very coarse $; \mathrm{C}=$ Coarse; $\mathrm{M}=$ Medium; $\mathrm{F}=$ Fine; $\mathrm{VF}=$ Very Fine; $\mathrm{SC}=$ Silt/Clay relation; $\mathrm{PD}=$ Particle Density; * = According soil taxonomy.

Table 2. Soil chemical characterization of the experimental area for the layer of $(0.0-0.10 \mathrm{~m})$

\begin{tabular}{|c|c|c|c|c|c|c|c|c|c|c|}
\hline $\mathrm{pH}$ & $\mathrm{Ca}^{2+}$ & $\mathrm{Mg}^{2+}$ & $\mathrm{Al}^{3+}$ & $\mathrm{H}+\mathrm{Al}^{3+}$ & SB & CEC & $\mathrm{Na}^{+}$ & SOM & $\mathrm{P}$ & $\mathrm{K}^{+}$ \\
\hline $\mathrm{H}_{2} \mathrm{O}_{(1: 2.5)}$ & \multicolumn{7}{|c|}{------------------------------------- $\mathrm{cmol}_{\mathrm{c}} \mathrm{dm}^{-3}{ }^{-3}$------------------------------------ } & $\mathrm{g} \mathrm{kg}^{-1}$ & \multicolumn{2}{|c|}{---- $\mathrm{mg} \mathrm{dm}^{-3}$---- } \\
\hline 5.3 & 1.89 & 1.43 & 0.30 & 8.33 & 3.46 & 11.79 & 0.06 & 49.52 & 1.82 & 28.37 \\
\hline
\end{tabular}

Note. $\mathrm{pH}=$ Hydrogen potential; $\mathrm{Ca}^{2+}=$ Calcium; $\mathrm{Mg}^{2+}=$ Magnesium; $\mathrm{Al}^{3+}=$ Exchangeable aluminum; $\mathrm{Na}^{+}=$ Sodium; $\mathrm{SB}=$ Sum of bases; $\mathrm{CEC}=$ Cation exchange capacity; $\mathrm{SOM}=$ Soil organic matter; $\mathrm{P}=$ Phosphorus; $\mathrm{K}^{+}$ $=$ Potassium.

The grasses were implanted in 2005 in experimental plots with dimensions of $10 \times 5 \mathrm{~m}$, adding up to $50 \mathrm{~m}^{2}$ of useful area (Figure 1). Plotswere 1 meter apart and blocks were 2 meters apart. 


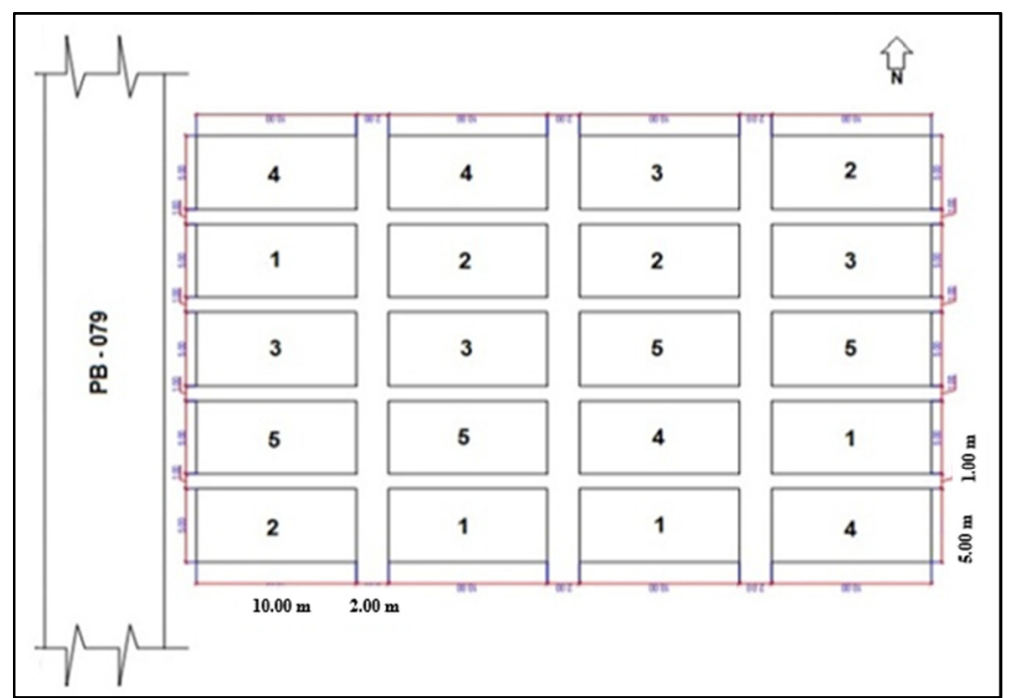

Figure 1. Detailing of experimental plots with evaluated treatments

Note. 1 = Brachiariadecumbens Stapf., 2 = Brachiaria brizantha, 3 = Brachiaria humidicola (Rendle) Schweickvr., 4 = Brachiaria brizantha MG5 and 5 = Brachiaria ruziziensis.

In the initial year of the experiment, $553 \mathrm{~kg} \mathrm{ha}^{-1}$ of NPK mixture (60-80-45) was fertilized in the experimental plots with the following nutrient sources: ammonium sulfate, triple superphosphate and potassium chloride. The fertilizer was sowed in the beginning of the rain season, after cutting and standardizing the grasses, a practice that was repeated until 2010 (Almeida et al., 2014). Later, the experiment was conducted annually, but without fertilization.

\subsection{Experimental Design}

The experimental design adopted was that of randomized complete blocks (RCB) with 5 treatments and 4 replications $(5 \times 4)$. The assessed treatments were the following: T1-Brachiaria decumbens Stapf., T2-Brachiaria brizantha, T3-Brachiaria humidicola (Rendle) Schweickvr., T4-Brachiaria brizantha cv. MG5-Vitória and T5-Brachiaria ruziziensis.

\subsection{Physical Attributes Analyzed}

In 2018, soil samples with disturbed and undisturbed structure were collected with the aid of the Uhland-type sampler in volumetric rings of $98.17 \mathrm{~cm}^{-3}$ in the layer of $0.0-0.10 \mathrm{~m}$. The samples with preserved structure were collected at the center of each experimental plot. They were then taken to the Laboratory of Soil Physical Analysis of the Center of Agricultural Sciences of the Federal University of Paraíba to determine the following attributes: Total porosity (TP), microporosity and macroporosity (Mi \& Ma), soil aeration capacity (SAC), bulk density $(\mathrm{BD})$, compaction degree $(\mathrm{CD})$, field capacity $(\theta \mathrm{FD})$, permanent wilting point $(\theta \mathrm{PWP})$, available water content $(\theta \mathrm{AWC})$, saturated hydraulic conductivity $(\mathrm{K} \theta)$, weighted meansdiameter of wet and dry aggregates (WMDda ad WMDwa), aggregate stability index (ASI), clay dispersed in water (CDW) and flocculation degree (FD), as described in Teixeira et al. (2017).

Total porosity was calculated through the humidity corresponding to the saturation volume, as described in Equation 1.

$$
T P\left(\mathrm{~m}^{3} \mathrm{~m}^{-3}\right)=\text { Mssat }-M d s / V t
$$

Where, Mssat is the mass of saturated soil $(\mathrm{kg})$; Mds is the mass of dry soil at $105{ }^{\circ} \mathrm{C}(\mathrm{kg})$ and $\mathrm{Vt}$ is the total volume of the soil sample in the cylinder $\left(\mathrm{cm}^{-3}\right)$.

Microporosity $\left(\mathrm{Mi}-\mathrm{m}^{3} \mathrm{~m}^{-3}\right.$ ), was calculated by applying the matrix potential of $6 \mathrm{kPa}$ in the tension table in saturated soil samples for the minimum period of 48 hours. Macroporosity $\left(\mathrm{Ma}-\mathrm{m}^{3} \mathrm{~m}^{-3}\right)$, was obtained through the difference between TP and Mi, according to Equations 2 and 3:

$$
\begin{gathered}
M i\left(\mathrm{~m}^{3} \mathrm{~m}^{-3}\right)=M s 6 k P a-M d s / V t \\
M a\left(\mathrm{~m}^{3} \mathrm{~m}^{-3}\right)=T P-M i
\end{gathered}
$$


Where, Mi is the microporosity of the soil; Ms6kPa is the humidity of the soil stabilized in the tension table; Mds is the mass of dry soil $105^{\circ} \mathrm{C}$; VT is the total volume of the cylinder; TP is the total porosity and Ma is the macroporosity of the soil.

The Soil Aeration Capacity variable (SAC), was determined as described in Equation 4:

$$
S A C\left(\mathrm{~m}^{3} \mathrm{~m}^{-3}\right)=P T-\theta F C / T P
$$

Where, TP is the total porosity of the soil $\left(\mathrm{m}^{3} \mathrm{~m}^{-3}\right) ; \theta \mathrm{FC}$ is the volumetric content of water in the field capacity $\left(\mathrm{m}^{3} \mathrm{~m}^{-3}\right)$ determined by the Richards extractor with an applied tension of $10 \mathrm{kPa}$.

Bulk density (BD) was determined through the ratio between dry soil mass/volume of soil sample in the cylinder Blake and Hartge (1986). To obtain the mass of dry soil the sample was placed in a heating chamber with temperature of $105^{\circ} \mathrm{C}$, for a 48 hours period until reaching a stable weight.

Compaction degree (CD) was determined according to the methodology proposed by Suzuki et al. (2007), in order to define the percentage of soil compaction in relation to its maximum (Equation 5). $1.85 \mathrm{~g} \mathrm{~cm}^{-3}$ was used as the maximum restrictive value of bulkdensity for medium texture Oxisol (Beutler et al., 2005).

$$
C D=B D / 1.85 \times 100
$$

Where, $\mathrm{CD}$ is the compaction degree (\%) and $\mathrm{BD}$ is the bulk density of the analyzed layer of the soil $(0.0-0.10$ $\mathrm{m})$.

The matrix potentials: $10 \mathrm{kPa}$ and $1500 \mathrm{kPa}$ were used to determine the moisture in the field capacity $\left(\theta_{\mathrm{FC}}\right)$ and the permanent wilting point ( $\theta \mathrm{PWP}$ ), as described in Teixeira (2017). Through the ratio between $\theta \mathrm{FC}-\theta \mathrm{PWP}$, the available water content range was obtained- $\theta \mathrm{AWC}\left(\mathrm{m}^{3} \mathrm{~m}^{-3}\right)$. The saturated hydraulic conductivity $\left(\mathrm{K} \theta-\mathrm{cm} \mathrm{h} \mathrm{h}^{-1}\right)$, was determined in undisturbed soil samples, with the aid of the constant charge permeameter and calculated with the following Equation 6:

$$
K \theta=(Q \times L) /(A \times H \times T)
$$

Where, $\mathrm{K} \theta$ is the saturated hydraulic conductivity; $\mathrm{Q}$ is the water volume percolated and colected in a measuring cylinder $\left(\mathrm{mL}^{-1}\right)$; L is the height of the soil block in $(\mathrm{cm})$; $\mathrm{A}$ is the area of the cylinder in $\left(\mathrm{cm}^{2}\right)$; $\mathrm{H}$ is the height of the soil block + water sheet $(\mathrm{cm})$ and $\mathrm{T}$ is the time in hours of collection of percolated water volume.

The determination of the weighted meansdiameter of soil wet aggregates (WMDwa) and weighted meansdiameter of soil dry aggregates (WMDwa) followed the methodology proposed by Kemper and Chepil (1965), with changes proposed by Carpenedo and Mielniczuk (1990) and Silva and Mielniczuk (1997), where the principle is to evaluate the resistance that the aggregates offer when submitted to oscillations in sieves in water. The aggregate stability index (ASI) was estimated by the ratio between the WMDwa/WMDda.

The clay dispersed in water was obtained by the means of soil granulometric analysis, according to the method of Bouyoucos densimeter method (Teixeira et al., 2017) however, without using chemical dispersant. For the total clay the same previous procedure was utilized, but using sodium hydroxide $(\mathrm{NaOH}-1 \mathrm{~N})$ as dispersant agent. The flocculation degree was obtained as described in Equation 7:

$$
D_{F L O}=\left(\text { Clay }- \text { Clay }_{H z 0}\right) / \text { Clay } \times 1000
$$

Where, $\mathrm{D}_{\mathrm{FLO}}$ is the flocculation degree $\left(\mathrm{g} \mathrm{kg}^{-1}\right)$, Clay is the clay content dispersed in sodium hydroxide- $\mathrm{NaOH}$ $\left(\mathrm{g} \mathrm{kg}^{-1}\right)$, and Clay $2 \mathrm{O}$ is the clay content dispersed in water $\left(\mathrm{g} \mathrm{kg}^{-1}\right)$. The silt clay relation $(\mathrm{S} / \mathrm{C})$, was determined by the ratio of silt content $\left(\mathrm{g} \mathrm{kg}^{-1}\right)$ and the total clay $\left(\mathrm{g} \mathrm{kg}^{-1}\right)$ in the soil sample.

\subsection{Statistical Analysis of Data}

The analysis of variance (ANAVA) was performed and the means were compared by Tukey's test $(p<0.05)$, using statistical software $R$ (R Devedolpemt, 2013). The Pearson correlation analysis (r) and the principal components analysis (PCA) were performed in order to evaluate the spatial dependence between the analyzed variables $(p<0.05)$.

\section{Results}

There was no significant statistical variation for total porosity (TP) $(p<0.05)$ level between the assessed treatments (Table 3), however the values varied from $0.44 \mathrm{~m}^{3} \mathrm{~m}^{-3}$ in the Brachiaria ruziziensis treatment to 0.49 $\mathrm{m}^{3} \mathrm{~m}^{-3}$ in the Brachiaria decumbens Stapf. treatment. Other variables such as macroporosity, microporosity, soil aeration capacity, bulk density and degree of compaction were not modified throughout different Brachiaria cultivars. 
Table 3. Mean values of soil porosities, soil aeration capacity, bulk density and compaction degree (CD) of an Oxisol under grasses in the Agreste region of Paraíba (0.0-0.10 m)

\begin{tabular}{|c|c|c|c|c|c|c|}
\hline Treatments & TP & $\mathrm{Ma}$ & $\mathrm{Mi}$ & SAC & $\mathrm{BD}$ & $\mathrm{CD}$ \\
\hline & -------- & - & $\mathrm{m}^{-3}--$ & ------------- & $\mathrm{g} \mathrm{cm}^{-3}$ & $\%$ \\
\hline Brachiaria decumbens & $0.49 \mathrm{a}$ & $0.16 \mathrm{a}$ & $0.33 \mathrm{a}$ & $0.29 \mathrm{a}$ & $1.18 \mathrm{a}$ & $63.8 \mathrm{a}$ \\
\hline Brachiaria brizantha & $0.46 \mathrm{a}$ & $0.13 \mathrm{a}$ & $0.33 \mathrm{a}$ & $0.21 \mathrm{a}$ & $1.20 \mathrm{a}$ & $65.0 \mathrm{a}$ \\
\hline Brachiaria humidicola & $0.46 \mathrm{a}$ & $0.14 \mathrm{a}$ & $0.32 \mathrm{a}$ & $0.25 \mathrm{a}$ & $1.19 \mathrm{a}$ & $64.2 \mathrm{a}$ \\
\hline B. brizantha cv. MG5 & $0.48 \mathrm{a}$ & $0.16 \mathrm{a}$ & $0.32 \mathrm{a}$ & $0.27 \mathrm{a}$ & $1.18 \mathrm{a}$ & $64.0 \mathrm{a}$ \\
\hline Brachiaria ruziziensis & $0.44 \mathrm{a}$ & $0.13 \mathrm{a}$ & $0.31 \mathrm{a}$ & $0.23 \mathrm{a}$ & $1.20 \mathrm{a}$ & $64.6 \mathrm{a}$ \\
\hline $\mathrm{CV}(\%)$ & 5.0 & 11.9 & 4.0 & 11.5 & 4.4 & 4.4 \\
\hline
\end{tabular}

Note. $\mathrm{TP}=$ Total porosity; $\mathrm{Ma}=$ Macroporosity; $\mathrm{Mi}=$ Microporosity; $\mathrm{SAC}=$ Soil aeration capacity; $\mathrm{BD}=\mathrm{Bu}$ lk density; $\mathrm{CD}=$ Compaction degree; $\mathrm{CV}=$ Coefficient of variation. Mean values followed by the same letter in the column do not differ by Tukey test $(p<0.05)$.

As for macroporosity (Ma), the values varied between 0.13 and $0.16 \mathrm{~m}^{3} \mathrm{~m}^{-3}$, with a higher average value in Brachiaria decumbens Stapf. and B. brizantha cv. MG5 treatments. Microporosity (Mi) varied from 0.31 to 0.33 $\mathrm{m}^{3} \mathrm{~m}^{-3}$, with a lower value in the Brachiaria ruziziensis treatment (Table 3).

It can be seen in Table 3 that the highest soil aeration capacity (SAC) value was found in the Brachiaria decumbens Stapf., treatment, but the SAC was not influenced by the different cultivars of Brachiaria. The bulk density (BD) ranged from 1.18 to $1.20 \mathrm{~g} \mathrm{~cm}^{-3}$, however with no significant statistical variation between the assessed treatments (Table 3). The compaction degree of the soil (CD) did not vary among the evaluated treatments $(p<0.05)$, as verified in Table 3 .

Table 4 shows the mean values of field capacity $(\theta \mathrm{FC})$, permanent wilting point $(\theta \mathrm{PWP})$, available water content $(\theta \mathrm{AWC})$ and saturated hydraulic conductivity $(\mathrm{K} \theta)$. It was verified that a significant statistical variation for the $\theta \mathrm{FC}(p<0.05)$. The values ranged from 0.205 to $0.243 \mathrm{~m}^{3} \mathrm{~m}^{-3}$, with a better result for the Brachiaria brizantha treatment $\left(0.243 \mathrm{~m}^{3} \mathrm{~m}^{-3}\right)$.

Table 4. Field capacity, permanent wilting point, available water content and saturated hydraulic conductivity of an Oxisol under grasses in the Agreste region of Paraíba (0.0-0.10 m)

\begin{tabular}{|c|c|c|c|c|}
\hline Treatments & $\theta \mathrm{FC}$ & $\theta \mathrm{PWP}$ & $\theta$ AWC & $\mathrm{K} \theta$ \\
\hline & \multicolumn{3}{|c|}{ - } & $\mathrm{cm} \mathrm{h}^{-1}$ \\
\hline Brachiaria decumbens & $0.205 \mathrm{~b}$ & $0.144 \mathrm{a}$ & $0.060 \mathrm{a}$ & $38.3 \mathrm{a}$ \\
\hline Brachiaria brizantha & $0.243 \mathrm{a}$ & $0.162 \mathrm{a}$ & $0.081 \mathrm{a}$ & $29.4 \mathrm{a}$ \\
\hline Brachiaria humidicola & $0.211 \mathrm{ab}$ & $0.144 \mathrm{a}$ & $0.067 \mathrm{a}$ & $40.7 \mathrm{a}$ \\
\hline B. brizantha $\mathrm{cv}$. MG5 & $0.206 \mathrm{ab}$ & $0.142 \mathrm{a}$ & $0.064 \mathrm{a}$ & $34.2 \mathrm{a}$ \\
\hline Brachiaria ruziziensis & $0.207 \mathrm{ab}$ & $0.149 \mathrm{a}$ & $0.058 \mathrm{a}$ & $37.1 \mathrm{a}$ \\
\hline $\mathrm{CV}(\%)$ & 5.5 & 7.7 & 12.4 & 43.6 \\
\hline
\end{tabular}

Note. $\theta \mathrm{FC}=$ Field capacity; $\theta \mathrm{PWP}=$ Permanent wilting point; $\theta \mathrm{AWC}=$ Available water content; $\mathrm{K} \theta=$ Saturated hydraulic conductivity; $\mathrm{CV}=$ Coefficient of variation. Mean values followed by the same letter in the column do not differ by Tukey test $(p<0.05)$.

Regarding saturated hydraulic conductivity $(\mathrm{K} \theta)$, it can be observed in Table 4, that there was no significant statistical variation between the treatments $(p<0.05)$, however the $\mathrm{K} \theta$ in the Brachiaria humidicola treatment was $40.7 \mathrm{~cm} \mathrm{~h}^{-1}$, higher than the others evaluated treatments, due to two main factors, the low degree of soil compaction and an increase in the total pore volume.

Table 5 shows the average values of mean weighted diameter of wet and dry aggregates (WMDwa and WMDda), aggregate stability index (ASI), clay dispersed in water (CDW) and flocculation degree (FD). It was verified that there was no significant statistical variation among the treatments evaluated $(p<0.05)$. 
Table 5. Mean weighted diameter, aggregates stability index, clay dispersed in water and flocculation degree of an Oxisol under grasses in the Agreste region of Paraíba (0.0-0.10 m)

\begin{tabular}{|c|c|c|c|c|c|}
\hline Treatments & WMDwa & WMDda & ASI & CDW & FD \\
\hline & \multicolumn{3}{|c|}{----------------- mm ---------------- } & \multicolumn{2}{|c|}{ 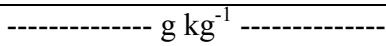 } \\
\hline Brachiaria decumbens & $2.44 \mathrm{a}$ & $3.12 \mathrm{a}$ & $0.782 \mathrm{a}$ & $19.25 \mathrm{a}$ & $942 \mathrm{a}$ \\
\hline Brachiaria brizantha & $3.13 \mathrm{a}$ & $3.52 \mathrm{a}$ & $0.889 \mathrm{a}$ & $3.25 \mathrm{a}$ & $992 \mathrm{a}$ \\
\hline Brachiaria humidicola & $2.75 \mathrm{a}$ & $3.21 \mathrm{a}$ & $0.856 \mathrm{a}$ & $22.75 \mathrm{a}$ & $934 \mathrm{a}$ \\
\hline B. brizantha cv. MG5 & $2.60 \mathrm{a}$ & $3.70 \mathrm{a}$ & $0.702 \mathrm{a}$ & $19.00 \mathrm{a}$ & $944 \mathrm{a}$ \\
\hline Brachiaria ruziziensis & $2.74 \mathrm{a}$ & $3.36 \mathrm{a}$ & $0.815 \mathrm{a}$ & $6.50 \mathrm{a}$ & $982 \mathrm{a}$ \\
\hline $\mathrm{CV}(\%)$ & 13.3 & 13.9 & 9.6 & 65.3 & 2.8 \\
\hline
\end{tabular}

Note. $\mathrm{WMDwa}=$ Weighted meansdiameter of wet aggregates; $\mathrm{WMDda}=$ Weighted meansdiameter of dry aggregates; $\mathrm{ASI}=$ Aggregates stability index $\mathrm{CDW}=$ Clay dispersed in water $\mathrm{FD}=$ Flocculation degree $\mathrm{CV}=$ Coefficient of variation. Mean values followed by the same letter in the column do not differ by Tukey test $(p<$ $0.05)$.

For the clay dispersed in water (CDW), it was verified that there was a reduction after nine years from the start of the experiment (Table 5), reflecting in high values for the flocculation degree of the soil, as for example $992 \mathrm{~g}$ $\mathrm{kg}^{-1}$ in the Brachiaria brizantha treatment. This action shows that the use of permanent grasses as soil cover, favors the formation of more stable aggregates in the soil, verified through the mean values of FD and CDW (Table 5).

Table 6 reveals the correlation values of the principal components for physical attributes of the Oxisol evaluated in the experiment. 
Table 6. Correlation values of the principal componentsanalysis (PCA) for physical attributes of an Oxisol under grasses in the Agreste region of Paraíba (0.0-0.10 m)

\begin{tabular}{|c|c|c|c|c|}
\hline \multirow{2}{*}{ Components of Variance } & \multicolumn{4}{|c|}{ Principal Components } \\
\hline & 1 & 2 & 3 & 4 \\
\hline Autovalues (\%) & 13.740 & 4.012 & 3.237 & 2.011 \\
\hline Proportions $(\%)$ & 50.738 & 17.444 & 14.073 & 8.745 \\
\hline Accumulated $(\%)$ & 59.73 & 77.18 & 91.25 & 100.00 \\
\hline Variables & \multicolumn{4}{|c|}{ 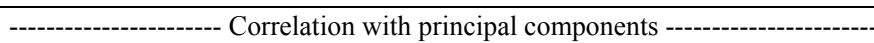 } \\
\hline TP & -0.180 & -0.108 & 0.367 & 0.182 \\
\hline $\mathrm{Ma}$ & -0.144 & -0.260 & 0.354 & 0.131 \\
\hline $\mathrm{Mi}$ & -0.012 & 0.065 & 0.518 & 0.232 \\
\hline $\mathrm{BD}$ & 0.264 & 0.027 & -0.059 & -0.102 \\
\hline $\mathrm{K} \theta$ & -0.191 & -0.010 & -0.357 & 0.204 \\
\hline $\mathrm{CD}$ & 0.264 & 0.027 & -0.059 & -0.102 \\
\hline WMDda & 0.081 & 0.277 & 0.275 & -0.419 \\
\hline WMDwa & 0.262 & 0.100 & 0.011 & 0.085 \\
\hline ASI & 0.219 & -0.061 & -0.221 & 0.285 \\
\hline$\theta \mathrm{FC}$ & 0.243 & 0.005 & 0.149 & 0.175 \\
\hline$\theta \mathrm{PWP}$ & 0.257 & -0.111 & 0.108 & 0.047 \\
\hline$\theta \mathrm{AWC}$ & 0.208 & 0.114 & 0.246 & 0.277 \\
\hline SAC & -0.257 & -0.065 & 0.146 & 0.025 \\
\hline Sand & -0.259 & 0.125 & -0.033 & -0.045 \\
\hline Silt & 0.204 & 0.196 & -0.135 & 0.325 \\
\hline Clay & 0.235 & -0.219 & 0.101 & -0.066 \\
\hline VCS & -0.180 & 0.346 & -0.121 & 0.104 \\
\hline $\mathrm{CS}$ & -0.236 & 0.129 & 0.096 & -0.260 \\
\hline MS & -0.193 & -0.321 & 0.130 & 0.090 \\
\hline FS & 0.036 & -0.469 & -0.076 & 0.200 \\
\hline VFS & 0.100 & 0.427 & 0.000 & 0.253 \\
\hline CDW & -0.231 & 0.159 & 0.004 & 0.282 \\
\hline FD & 0.235 & -0.149 & -0.018 & -0.270 \\
\hline
\end{tabular}

Note. $\mathrm{TP}=$ Total porosity, $\mathrm{Ma}=$ Macroporosity, $\mathrm{Mi}=$ Microporosity, $\mathrm{BD}=$ Bulk density, $\mathrm{K} \theta=$ Saturated hydraulic conductivity, $\mathrm{CD}=$ Compaction degree, $\mathrm{WMDwa}=$ Weighted meansdiameter of wet aggregates; $\mathrm{WMDda}=$ Weighted meansdiameter of dry aggregates, $\mathrm{ASI}=$ Aggregates stability index, $\theta \mathrm{FC}=$ Field capacity, $\theta \mathrm{PWP}=$ Permanent wilting point, $\theta \mathrm{AWC}=$ Available water content, $\mathrm{SAC}=$ Soil aeration capacity, $\mathrm{VCS}=$ Very coarse sand, $\mathrm{CS}=$ Coarse sand, $\mathrm{MS}=$ Medium sand, FS $=$ Fine sand, VFS = Very fine sand, CDW = Clay dispersed in water and $\mathrm{FD}=$ Flocculation degree.

It can be observed that $77.1 \%$ of the coefficient of variation was explained by quadrants 1 and 2 for most assessed attributes. The Brachiaria brizantha and Brachiaria ruziziensis components were the most influential on the correlation values of the analyzed variables (Figure 2). 


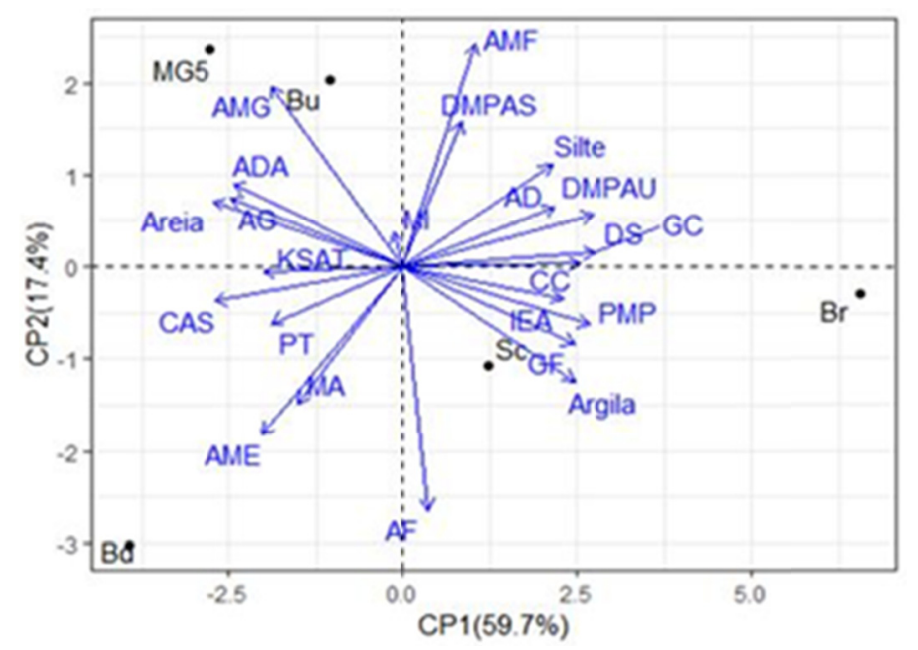

Figure 2. Principal components analysis for physical attributes of an Oxisol under grasses in the Agreste region of Paraíba (0.0-0.10 m)

Note $. \mathrm{CP}=$ Principal component, $\mathrm{Bd}=$ Brachiaria decumbens, $\mathrm{Bu}=$ Brachiaria humidicola, $\mathrm{Br}=$ Brachiaria brizantha, $\mathrm{Sc}=$ Brachiaria ruziziensis, MG5 $=$ Brachiaria brizantha $\mathrm{MG} 5 \mathrm{cv}$. Vitória. $\mathrm{PT}=$ Total porosity, $\mathrm{Ma}=$ Macroporosity, $\mathrm{Mi}=$ Microporosity, $\mathrm{DS}=$ Bulk density, $\mathrm{K}_{\mathrm{SAT}}=$ Saturated hydraulic conductivity, $\mathrm{GC}=$ Compaction degree, DMPAs $=$ Mean weighted diameter of dry aggregates, DMPAu $=$ Mean weighted diameter of wet aggregates, IEA = Aggregates stability index, $\mathrm{CC}=$ Field capacity, $\mathrm{PMP}=$ Permanent wilting point, $\mathrm{AD}=$ Available water content, $\mathrm{CAS}=$ Soil aeration capacity, $\mathrm{AMG}=$ Very coarse sand, $\mathrm{AG}=$ Coarse sand, $\mathrm{AME}=$ Medium sand, $\mathrm{AF}=$ Fine sand, $\mathrm{AMF}=$ Very fine sand, $\mathrm{ADA}=$ Clay dispersed in water and $\mathrm{GF}=$ Flocculation degree.

The main variables influenced by the Brachiaria brizantha MG5 cv. Vitória and Brachiaria humidicola components were the clay dispersed in water and the coarse fractions of Sand (Coarse and very coarse sand). For the Brachiaria ruziziensis component, the most important attributes were $\theta \mathrm{FC}, \theta \mathrm{PWP}$, ASI and FD. This result shows that $B$. ruziziensis, through the action of its aggressive root system, favors improvements in soil physical attributes used as indicators of soil quality, especially those related to structure such as FD and ASI.

Brachiaria brizantha was the most influential component on the variability of the soil attributes verified in the principal component's analysis (Figure 2). The BD, CD, Wet and WMDwa and WMDdawere the most influenced attributes. These results demonstrate the efficacy of this species in soil management and conservation. The attribute that was less influenced by the different grasses treatments was microporosity, since it is sensitive to variations in the texture of the soil and not to management practices.

Table 7 shows the correlation values for the physical attributes of Oxisol under different grasses cultivars. The criteria for interpretation of the Pearson correlation coefficient ( $\mathrm{r}$ ) used in this study followed the one proposed by (Oliveira et al., 2018), being: $0.7 \leq \mathrm{r} \leq 1.0$ for strong correlation; $0.4 \leq \mathrm{r}<0.6$ for moderate correlation; $0.1 \leq \mathrm{r}$ $<0.3$ for weak correlation and $0.0 \leq \mathrm{r}<0.1$ for null correlation. 
Table 7. Pearson correlation (r) for physical attributes of an Oxisol under grasses in the Agreste region of Paraíba $(0.0-0.10 \mathrm{~m})$

\begin{tabular}{|c|c|c|c|c|c|c|c|c|c|c|c|c|c|c|c|}
\hline & TP & MA & MI & $\mathrm{BD}$ & $\mathrm{CD}$ & $\mathrm{K} \theta$ & WMDda & WMDwa & ASI & $\theta \mathrm{FC}$ & $\theta_{\text {PWP }}$ & $\theta_{\text {AWC }}$ & SAC & CDW & FD \\
\hline TP & 1 & $0.66^{* *}$ & $0.65^{* *}$ & - & - & - & - & - & - & - & - & - & $0.85^{* * *}$ & - & - \\
\hline MA & & 1 & - & $-0.55^{*}$ & $-0.55^{*}$ & - & - & - & - & - & - & - & $0.65^{* *}$ & - & - \\
\hline MI & & & 1 & - & - & - & - & - & - & - & - & - & - & - & - \\
\hline $\mathrm{BD}$ & & & & 1 & $1^{* * *}$ & - & - & - & - & $0.45^{*}$ & $0.55^{*}$ & - & $-0.52^{*}$ & - & - \\
\hline $\mathrm{CD}$ & & & & & 1 & - & - & - & - & $0.45^{*}$ & $0.55^{*}$ & - & $-0.52^{*}$ & - & - \\
\hline $\mathrm{K} \theta$ & & & & & & 1 & - & - & $0.48^{*}$ & - & - & - & - & - & - \\
\hline WMDda & & & & & & & 1 & $0.70^{* * *}$ & - & - & - & - & - & - & - \\
\hline WMDwa & & & & & & & & 1 & $0.48^{*}$ & $0.49^{*}$ & - & $0.59^{* *}$ & - & - & - \\
\hline ASI & & & & & & & & & 1 & - & - & - & $0.47^{*}$ & $0.46^{*}$ & - \\
\hline$\theta_{\mathrm{FC}}$ & & & & & & & & & & 1 & $0.83^{* * *}$ & $0.72^{* * *}$ & $-0.71^{* * *}$ & - & - \\
\hline$\theta_{\mathrm{PWP}}$ & & & & & & & & & & & 1 & - & $-0.57^{*}$ & - & - \\
\hline$\theta_{\mathrm{AWC}}$ & & & & & & & & & & & & 1 & $-0.57^{* *}$ & - & - \\
\hline SAC & & & & & & & & & & & & & 1 & - & - \\
\hline CDW & & & & & & & & & & & & & & 1 & $1^{* * *}$ \\
\hline FD & & & & & & & & & & & & & & & 1 \\
\hline
\end{tabular}

Note. $*=$ Meaningful at $(p<0.05) ; * *=$ Meaningful at $(p<0.01) ; * * *=$ Meaningful at $(p<0.001) ;(-)=$ Not meaningful; WMDwa $=$ Weighted meansdiameter of wet aggregates; WMDda $=$ Weighted meansdiameter of dry aggregates; $\mathrm{ASI}=$ Aggregates stability index $\mathrm{CDW}=$ Clay dispersed in water; $\mathrm{FD}=$ Flocculation degree; $\theta_{\mathrm{FC}}=$ Field capacity; $\theta_{\mathrm{PWP}}=$ Permanent wilting point; $\theta_{\mathrm{AWC}}=$ Available water content; $\mathrm{K}_{\mathrm{SAT}}=$ Saturated hydraulic conductivity; $\mathrm{PT}=$ Total porosity; $\mathrm{Ma}=$ Macroporosity; $\mathrm{Mi}=$ Microporosity; $\mathrm{SAC}=$ Soil aeration capacity; $\mathrm{BD}$ $=$ Bulk density; $\mathrm{CD}=$ Compaction degree.

The most significant values of positive correlation were verified between CDW and FD $(r=1.0)$, being considered strong, since they are inherently linked attributes. The most significant negative correlation was found between SAC and $\theta \mathrm{FC}(\mathrm{r}=-0.71)$. Another strong correlation was found between $\theta$ FCand $\theta \mathrm{PWP}(\mathrm{r}=$ 0.83 ). The $\theta$ AWC attribute presented $r=0.72$ with $\theta$ FC. However, it can be observed that $\theta$ AWC did not present a significant correlation value with $\theta \mathrm{PWP}$, showing that it is an attribute which is not dependent on high matrix potentials. The correlation between PT and SAC was $r=0.85$, which is considered strong. The SAC showed moderate correlation with $\mathrm{Ma}(\mathrm{r}=0.85)$.

One last strong correlation was verified between WMDwa and WMDda with $r=0.70$, this means that the increase in the mean weighted diameter of dry aggregates leads to increase in the mean weighted diameter of wet aggregates and the aggregates stability index. It is also important to highlight the moderate correlation values found between $\theta \mathrm{PWP}, \mathrm{CD}$ and $\mathrm{BD}$ with $\mathrm{r}=0.55$.SAC showed strong negative correlation with $\theta \mathrm{FC} \mathrm{r}=-0.71$.

There was a moderate negative correlation between the physical attributes of Ma, $\mathrm{BD}$ and $\mathrm{CD} r=-0.55$. Other values of moderate negative correlation were verified between $\mathrm{BD}, \mathrm{CD}$ and $\mathrm{SAC}(\mathrm{r}=-0.52)$. There was a strong and perfectly positive correlation $(\mathrm{r}=1.0)$ between $\mathrm{CD}$ and $\mathrm{BD}$.

\section{Discussion}

The permanence of total porosity (TP) values above $0.44 \mathrm{~m}^{3} \mathrm{~m}^{-3}$ in all assessed treatments is related to the keeping of vegetation cover and to the development of the grass root system, which grows favoring the formation of porous spaces in the soil. Other factors such as reduction of soil mobilization and constant deposition of organic matter on the surface favor the increase in the pore volume of the soil (Melo et al., 2016; Sales et al., 2018), due to the action of microorganisms, which bind the particles together and contribute to the formation of pores between the aggregates of the soil.

Another perceived factor concerns the critical macroporosity values of the soil, as it was observed that all values were above the critical limit, which according to Reichert et al. (2007) is $0.10 \mathrm{~m}^{3} \mathrm{~m}^{-3}$. Unlike macroporosity that fits into the structural porosity category, the microporosity is classified as a component of soil textural porosity and is therefore little influenced by soil management practices (Ramos et al., 2014).

The soil aeration capacity (SAC) was not influenced by the different cultivars of Brachiaria. However, the values ranged from 0.21 to $0.29 \mathrm{~m}^{3} \mathrm{~m}^{-3}$, being above the critical limit used as standard for most soils and crops, which according to Tormena et al. (2002) is $0.10 \mathrm{~m}^{3} \mathrm{~m}^{-3}(10 \%)$. When SAC is greater than $0.34 \mathrm{~m}^{3} \mathrm{~m}^{-3}$, some 
factors start to affect the development of crops, mainly due to problems related to water retention in the soil (Silva et al., 2018).

The lowest bulk density (BD) value was verified in the Brachiaria decumbens Stapf. and B. brizantha cv. MG5 treatments $=1.18 \mathrm{~g} \mathrm{~cm}^{-3}$, well below the critical range, which is 1.30 to $1.40 \mathrm{~g} \mathrm{~cm}^{-3}$ for soils of clayey texture (Reinert et al. 2008). When BD values are above the critical limit, some abnormalities will affect the development of the plants, due to the reduction in aeration capacity and the low power of roots penetration in compacted layers of the soil (Reinert et al., 2008). The BD values found in this study were much lower than those verified by Tormena et al. (2002), while evaluating the influence of BD and TP on the development of Brachiaria brizantha on Yellow Oxisol, with values between 1.43 and $1.57 \mathrm{~g} \mathrm{~cm}^{-3}$.

The compaction degree of the soil (CD) did not vary among the evaluated treatments $(p<0.05)$. However, the values obtained remained between 63.8 and $65.0 \%$, a trend verified as a function of the BD increase, since the $\mathrm{CD}$ is closely related to BD. While working with CD evaluation in Oxisol and Argisol, Suzuki et al. (2007) found that the restrictive $\mathrm{CD}$ for most crops is $75.0 \%$, well above the maximum value verified in this study, which was $65.0 \%$ in the Brachiaria brizantha treatment.

It is observed that there is a direct relationship between the volume of water in the field capacity and the degree of soil compaction in the Brachiaria brizantha treatment. The $65.0 \%$ elevation in the CD favored not only the water volume in the $\theta \mathrm{FC}$, but also the water volumes in the $\theta \mathrm{PWP}$ and the $\theta \mathrm{AWC}$. Several factors are involved in the increase of $\theta \mathrm{FC}$ in the Brachiaria brizantha treatment when compared to the other treatments, among them are the greater presence of vegetal cover in surface, greater volume of micropores and reduction in SAC.

However, the accumulation of organic matter on the surface by the input of dry biomass from the grass Brachiaria decumbens Stapf. may have favored the increase in the water volume stored under $\theta \mathrm{FC}$ (Silva et al., 2019). Therefore, the maintenance of vegetal residues on the surface reduces the loss of organic carbon through the formation of aggregates and, among other benefits it leads to the preservation of soil water content (Carmo et al., 2012).

Aggregate stability index (ASI) values shown in table 5 were higher than those verified by Almeida et al. (2014), in a work done on the same experimental area, where it was evaluated the effect of fertilization on caespitosa and decumbens Poaceae over soil aggregation. They found ASI values of 0.790 in 2010 for the Brachiaria brizantha treatment. Nine years later the ASI found for the same treatment was 0.889 , an increase of $11.0 \%$. Brandão and Silva (2012) working with formation and stabilization of aggregates by the Brachiaria root system, observed that the use of grasses increased the WMDwa and the ASI of the soil. They concluded that this process ocurred due to the release of exudates and the greater density of grasses' roots.

The continuous supply of organic matter by grasses or root excretions, whose products are composed of organic molecules in several stages of decomposition, act as agents for formation and stabilization of aggregates, providing improvements in soil structure (Bonini \& Alves, 2011).

The aggregation arising from the union of particles (clay-ion-organic matter, sand and silt) in environments under conservationist management reduces the impact of rain drops on the clay dispersion (Sales et al., 2010). It is then verified the great importance in managing the soil, permanently keeping the vegetation cover on the surface.

On the coefficient of variation (CV) of the statistical analysis, it is noted that the majority of the treatments presented low CV values, which should be equal to or less than $10.0 \%$. Taking into account the classification proposed by Oliveira et al. (2018), the attributes that presented the lowest CV were PT, Mi, BD and CD (Table 3), $\theta$ FCe $\theta$ PWP (Table 4), ASI and FD (Table 5), all with values ranging from 4 to $9.6 \%$, with the lowest CV being $2.2 \%$ for the FD attribute. These values indicate that they are attributes that can be used as indicators of soil quality, due to the high reliability presented (Cavallini et al., 2010).

In relation to Pearson's correlation, the higher the content of clay dispersed in water, the lower the flocculation degree of the soil. As the CDW values were low for the conditions to which the soil was evaluated, it favored an increase in the FD of the soil.

The strong positive correlation found between $\theta \mathrm{FC}$ and $\mathrm{\theta PWP}$ it indicates that both attributes have a close relationship with the soil matrix, directly influencing the water available to the plants. The SAC showed moderate correlation with Macroporosity, therefore, the increase of macroporosity contributes with the increase of the aeration capacity of the soil. As the pore classes of the soil are interconnected, the modification of one can positively or negatively affect the variation of the other. Specially the structural pores, because they are more sensitive to soil management practices (Klein et al., 2008). 
The correlation verified between $\theta$ PWP, CD and BD, means that the higher the compaction degree of the soil, the greater the water potential in the $\theta \mathrm{PWP}$, due to the reduction of larger pore spaces such as Ma. Rodrigues et al. (2015) verified a negative correlation between $\theta \mathrm{PWP}$ and $\mathrm{BD}$, with an average value of $\mathrm{r}=-1.0$ for a medium texture Red Oxisol. SAC showed strong negative correlation with $\theta_{\mathrm{FC}}$, this shows that the larger the volume of water retained as $\theta \mathrm{FC}$, the smaller are the spaces occupied by air.

There was a moderate negative correlation between the physical attributes of $\mathrm{Ma}, \mathrm{BD}$ and $\mathrm{CD}$, therefore, these attributes are very sensitive to changes in soil management. Because, the larger the $\mathrm{BD}$, the smaller the volume of Ma in the soil. Sampietro et al. (2015) verified the reduction of Ma of the soil with the increase of BD. This increase in BD can lead to changes in the physical and hydraulic attributes of the soil, especially the retention and availability of water to the plants. Montanari et al. (2013) verified that the increase in BD promoted a decrease in the production of bean pods cultivated on Oxisol in the state of Mato Grosso do Sul. In their interpretation this fact is due to the increase in the compaction degree and reduction of soil porosity. Because unlike grasses, legumes have a less aggressive root system, reducing to a certain extent the volume of soil explored and performing lower absorption of water and nutrients (Melo et al., 2016).

The correlation verified between $\mathrm{BD}, \mathrm{CD}$ and $\mathrm{SAC}$, show it SAC is an attribute directly related to the increase of density and, that it can be used as an indicator of soil quality, for indirectly predicting the compaction degree of the evaluated soil layer.

\section{Conclusion}

After the 13 years period, it was concluded that Brachiaria brizantha, promoted improvements to the field capacity in the Oxisol. The other attributes were not significantly modified after the same time lapse. Principal component analysis showed that the correlation values were more significant for the Brachiaria brizantha component. Pearson's correlation was more significant between field capacity and soil aeration capacity.

\section{References}

Almeida, D. J., Silva, I. F., Silveira, F. P. M., Santiago, R. D., \& Costa, J. R. C. (2014). Caespitosa and decumbens Poaceae fertilized with NPK: Effects on soil aggregation. Pesquisa Agropecuária Tropical, 44, 50-55. https://doi.org/10.1590/S1983-40632014000100002

Beutler, A. N., Centurion, J. F., Roque, C. G., \& Ferraz, M. V. (2005). Densidade relativa ótima de Latossolos Vermelhos para a produtividade de soja. Revista Brasileira de Ciência do Solo, 29, 843-849. https://doi.org/ $10.1590 / \mathrm{S} 0100-06832005000600002$

Blake, G. R., \& Hartge, K. H. (1986). Bulk density. In A. Klute (Ed.), Methods of Soil Analysis: I. Physical and Mineralogical Methods (1st ed., pp. 425-442). Madison: Soil Science Society American. https://doi.org/ 10.2136/sssabookser5.1.2 ed.c13

Bonini, C. S. B., \& Alves, M. C. (2011). Estabilidade de agregados de um Latossolo Vermelho degradado em recuperação com adubos verdes, calcário e gesso. Revista Brasileira de Ciência do Solo, 35, 1263-1270. https://doi.org/10.1590/S0100-06832011000400019

Braga, M. B., Marquelli, W. A., Resende, G. M., Moura, M. S. B, Costa, N. D., Calgoro, M., \& Correia, J. S. (2017). Coberturas do solo e uso de manta agrotêxtil (TNT) no cultivo do meloeiro. Horticultura Brasileira, 35, 147-153. https://doi.org/10.1590/S0102-053620170123

Brandão, E. D., \& Silva, I. F. (2012). Formação e estabilização de agregados pelo sistema radicular de braquiária em um Nitossolo Vermelho. Ciência Rural, 42, 1193-1199. https://doi.org/10.1590/S0103-84782012 000700009

Carmo, F. F., Figueirêdo, C. C., Ramos, M. L. G., Vivaldi, A., \& Araújo, L. G. (2012). Frações granulométricas da matéria orgânica em latossolo sob plantio direto com gramineas. Bioscience Journal, 28, 420-431. Retrieved from https://www.seer.ufu.br/index.php/biosciencejournal/article/view/12351

Carpenedo, V., \& Mielniczuk, J. (1990). Estado de agregação e qualidade de agregados de Latossolos Roxos, submetidos a diferentes sistemas de manejo. Revista Brasileira de Ciência do Solo, 14, 99-105.

Costa, D. M. A., Melo, H. N. S., \& Ferreira, S. R. (2007). Eficiência da cobertura morta na retenção de umidade no solo. Holos, 23, 59-69. https://doi.org/10.15628/holos.2007.6

Cavallini, M. C., Andreoti, M., Oliveira, L. L., Pariz, C. M., \& Carvalho, M. P. (2010). Relações entre produtividade de Brachiaria brizantha e atributos físicos de um Latossolo do cerrado. Revista Brasileira de Ciência do Solo, 34, 1007-1015. https://doi.org/10.1590/S0100-06832010000400001 
Gasparetto, E. C., Braida, J. A., Carneiro, M., Scariot, J. J., \& Tabelka, C. L. (2009). Grau de floculação da argila de um Latossolo Vermelho utilizado com lavoura e mata nativa. Synergismus Scyentifica, 4, 1-3. Retrieved from https://revistas.utfpr.edu.br/pb/index.php/SysScy/article/view/622

Guimarães, D. V., Gonzaga, M. I. S., Araújo, E. M., Melo Neto, J. O., \& Tenil Júnior, J. I. (2014). Impacto do cultivo de citros sobre a qualidade física de um Argissolo Amarelo em Sergipe. Revista Caatinga, 27, 183-189. Retrieved from https://periodicos.ufersa.edu.br/index.php/caatinga/article/view/2638

Kemper, W. D., \& Chepil W. S. (1965). Size distribution of aggregates. In C. A. Black (Ed.), Methods of soil analysis (1st ed., pp. 499-510). Madison: American Society of Agronomy.

Klein, V. A., Vieira, M. L., Durigon, F. F., Massing, J. P., \& Favero, F. (2008). Porosidade de aeração de um Latossolo Vermelho e rendimento de trigo em plantio direto escarificado. Ciência Rural, 38, 365-371. https://doi.org/10.1590/S0103-84782008000200011

Lima, J. R. S., Souza, E. S., Antonino, A. C. D., Silva, I. F., Corrêa, M. M., \& Lira, C. A. B. O. (2014). Atributos físico-hídricos de um Latossolo Amarelo cultivado e sob mata nativa no Brejo Paraibano. Revista Brasileira de Ciências Agrárias, 9, 599-605. https://doi.org/agraria.v9i4a3532

Melo, G. B., Pereira, M. G., Perin, A., Guareschi, R. F., \& Soares, P. F. C. (2016). Estoques e frações da matéria orgânica do solo sob os sistemas plantio direto e convencional de repolho. Pesquisa Agropecuária Brasileira, 51, 1511-1519. https://doi.org/10.1590/S0100-204X2016000900050

Montanari, R. P., Douglas, M. P., Silva Júnior, C. A., Carvalho, M. de P., Gioia, M. T., Dalchiavon, F. C., \& Paz González, A. (2013). Correlação entre produção de feijão e atributos físicos de um Latossolo em Mato Grosso do Sul. Revista Ceres, 60, 772-784. https://doi.org/10.1590/S0034-737X2013000600005

Oliveira, D. G., Reis, E. F., Medeiros, J. C., Martins, M. P. O., \& Umbelino, A. S. (2018). Correlação espacial de atributos físicos do solo e produtividade de tomate industrial. Revista Agro@mbiente On-line, 12, 1-10. https://doi.org/10.18227/1982-8470ragro.v12i1.4211

R Development Core Team. (2013). R: A language and environment for statistical computing. Vienna: R Foundation for Statistical Computing. Retrieved from https:/www.r-project.org

Ramos, F. T., Maia, J. C. S., Roque, M. W., \& Azevedo, E. C. (2014). Qualidade física de um NeossoloQuartzarênico estimada via índice S e área sob a curva. Enciclopédia Biosfera, 10, 2543-2561. Retrieved from https://www.conhecer.org.br/enciclop/2014a/AGRARIAS/qualidade\%20fisica.pdf

Redin, M., Santos, G. F., Miguel, P., Denega, G. L., Lupatini, M., Doneda, A., \& Souza, E. L. (2011). Impactos da queima sobre atributos químicos, físicos e biológicos do solo. Ciência Florestal, 4, 381-392. https://doi.org/10.5902/198050983243

Reichert, J. M., Suzuki, L. E. A. S., \& Reinert, D. J. (2007). Compactação do solo em sistemas agropecuários e florestais: Identificação, efeitos, limites críticos e mitigação. In C. A. Ceretta, L. S. Silva, \& J. M. Reichert (Eds.), Tópicos em ciência do solo (5th ed. p. 496). Viçosa: Sociedade Brasileira de Ciência do Solo.

Reinert, D. J., Albuquerque, J. A., Reichert, J. M., Aita, C., \& Andrade, M. M. C. (2008). Limites críticos de densidade do solo para o crescimento de raízes de plantas de cobertura em Argissolo Vermelho. Revista Brasileira de Ciência do Solo, 32, 1805-1816. https://doi.org/10.1590/S0100-06832008000500002

Rodrigues, R. R., Ferrari, J. L., Lima, W. L., Reis, E. F., \& Jaeggi, P. C. (2015). Caracterização físico-hídrica do solo em diferentes coberturas em floresta piloto após quatro anos de implantação. Agrarian Academy, 2, 10-20. https://doi.org/10.18677/Agrarian_Academy_013

Sales, A., Silva, A. R., Veloso, C. A. C., Carvalho, E. J. M., \& Miranda, B. M. (2018). Carbono orgânico e atributos físicos do solo sob manejo agropecuário sustentável na Amazônia legal. Colloquium Agrariae, 14, 1-15. https://doi.org/10.5747/ca.2018.v14.n1.a185

Sales, L. E. O., Carneiro, M. A. C., Severiano, E. C., Oliveira, G. C., \& Ferreira, M. M. (2010). Qualidade física de NeossoloQuartzarênico submetido a diferentes sistemas de uso agrícola. Ciência e Agrotecnologia, 4, 667-674. https://doi.org/10.1590/S1413-70542010000300020.

Sampietro, J. A., Lopes, E. S., \& Reichert, J. M. (2015). Compactação causada pelo tráfego de Fellerbuncher e skidder em um Neossolo Regolítico sob distintas umidades. Ciência Florestal, 25, 239-248. https://doi.org/ 10.1590/1980-509820152505239 
Santos, G. G., Silveira, P. M., Marchão, R. L., Petter, F. A., \& Becquer, T. (2012). Atributos químicos e estabilidade de agregados sob diferentes culturas de cobertura em Latossolo do cerrado. Revista Brasileira de Engenharia Agrícola e Ambiental, 16, 1171-1178. https://doi.org/10.1590/S1415-43662012001100005

Santos, H. G., Jacomine, P. K. T., Anjos, L. H. C., Oliveira, V. Á., Lumbreras, J. F., Coelho, M. R., ... Cunha, T. J. F. (2018). Sistema Brasileiro de Classificação de Solos (5th ed. p. 353). Brasília: Empresa Brasileira de Pesquisa Agropecuária.

Silva, I. F., \& Mielniczuk, J. (1997). Ação do sistema radicular de plantas na formação e estabilização de agregados do solo. Revista Brasileira de Ciência do Solo, 21, 113-117. https://doi.org/10.1590/ S0100-06831997000300012

Silva, P. L. F., Oliveira, F. P., Borba, J. O. M., Tavares, D. D., Amaral, A. J., \& Martins, A. F. (2018). Solos arenosos para Sistemas de integração lavoura-pecuária-floresta em Arez, Rio Grande do Norte. Revista Verde de Agroecologia e Desenvolvimento Sustentável, 13, 581-589. https://doi.org/10.18378/rvads. v13i5.6246

Silva, P. L. F., Oliveira, F. P., Pereira, W. E., Borba, J. O. M., Tavares, D. D., Santos, T. E. D., \& Martins. A. F. (2019). Estoques de carbono e retenção hídrica em biomassa de gramíneas no agreste da Paraíba. Brazilian Journal of Biossystems Engineering, 13, 155-167. https://doi.org/10.18011/bioeng2019v13n2p155-167

Silva, W., Silveira, A. M. E., Tavares, R., Martins, G. S., \& Lima, J. S. (2018). Cobertura do solo com material orgânico no desenvolvimento inicial de sorgo forrageiro. Agrarian Academy, 5, 122-129. https://doi.org/ 10.18677/AgrarianAcademy2018a12

Soto, M. A. A., \& Kiang, C. H. (2018). Avaliação da condutividade hidráulica em dois usos do solo na região central do Brasil. Revista Brasileira de Ciências Ambientais, 47, 1-11. https://doi.org/10.5327/Z2176-947 820180169

Suzuki, L. E. A. S, Reichert, J. M., Reinert, D. J., \& Lima, C. L. R. (2007). Grau de compactação, propriedades físicas e rendimento de culturas em Latossolo e Argissolo. Pesquisa Agropecuaria Brasileira, 42, 1159-1167. https://doi.org/10.1590/S0100-204X2007000800013

SUDENE (Superintendência de Deselvolvimento do Nordeste). (2017). Delimitação do semiárido Brasileiro. Retrieved from https://www.sudene.gov.br/delimitacao-do-semiarido

Teixeira, P. C., Donagemma, G. K., Fontana, A., \& Teixeira, W. G. (2017). Manual de métodos de análise de solo (3rd ed. p. 573). Brasília: Empresa Brasileira de Pesquisa Agropecuária. Retrieved from https://www.infoteca.cnptia.embrapa.br/handle/doc/1085209

Tormena, C. A., Barbosa, M. C., Costa, A. C. S., \& Gonçalves, A. C. A. (2002). Densidade, porosidade e resistência à penetração em Latossolo cultivado sob diferentes sistemas de preparo do solo. Scientia Agricola, 59, 795-801. https://doi.org/10.1590/S0103-90162002000400026

\section{Copyrights}

Copyright for this article is retained by the author(s), with first publication rights granted to the journal.

This is an open-access article distributed under the terms and conditions of the Creative Commons Attribution license (http://creativecommons.org/licenses/by/4.0/). 